\title{
ANALISIS KESESUAIAN MATERI IPA BUKU SISWA KELAS IV SD TERHADAP STANDAR ISI KURIKULUM 2013
}

\author{
Mera Putri Dewi, Taufina
}

Surel: meraputridewi14@gmail.com

\begin{abstract}
Science learning is one of the contents of learning in the 2013 curriculum. Learning material in science content has been contained in integrated thematic books. Although the books published by the government have been prepared as well as possible but according to the changing times, the books will continue to be improved and changed to meet the development of the era itself. Therefore, inputs are needed to improve the quality of the book. Therefore, the Science Material in the student book must refer to the 2013 curriculum content standards. The purpose of this study is to see the suitability of the grade IV science books for elementary school students to the 2013 curriculum content standards. The research method used is content analysis. From the results of the analysis it can be seen that from the nine scope of the scope of natural science materials in the 2013 curriculum content standards there are three science materials that are not presented in student books, namely the shape of objects, plant breeding, and materials on climate and weather. In addition, there are two additional materials in the student book which are about the properties of sound and the properties of light that are not contained in the 2013 curriculum content standards
\end{abstract}

Keywords: Science Materials, Student Books, Content Standard, 2013 Curriculum

\begin{abstract}
ABSTRAK
Pembelajaran IPA merupakan salah satu muatan pembelajaran dalam kurikulum 2013. Materi pembelajaran dalam muatan IPA sudah dimuat dalam buku tematik terpadu. Meski buku yang diterbitkan oleh pemerintah telah disusun dengan sebaik-baiknya namun sesuai perubahan zaman, maka buku akan terus diperbaiki dan dirubah untuk memenuhi perkembangan zaman itu sendiri. Oleh sebab itu, diperlukan masukan-masukan demi meningkatkan kualitas buku. Oleh karena itu, Materi IPA dalam buku siswa harus mengacu pada standar isi kurikulum 2013. Tujuan penelitian ini yaitu untuk melihat kesesuaian materi IPA buku siswa kelas IV SD terhadap standar isi kurikulum 2013. Metode penelitian yang digunakan yaitu analisis konten. Dari hasil analisis dapat diketahui bahwa dari sembilan runag lingkup materi IPA dalam standar isi kurikulum 2013 ada tiga materi IPA yang tidak disajikan dalam buku siswa yaitu wujud benda, perkembangbiakan tanaman, serta materi tentang iklim dan cuaca. Selain itu, terdapat dua materi tambahan dalam buku siswa yaitu mengenai sifat-sifat bunyi dan sifat-sifat cahaya yang tidak terdapat dalam standar isi kurikulum 2013.
\end{abstract}

Kata Kunci: Materi IPA, Buku Siswa, Standar Isi, Kurikulum 2013 



\section{PENDAHULUAN}

Pembelajaran IPA merupakan salah satu muatan pembelajaran dalam kurikulum 2013 yang menuntun siswa untuk dapat berpikir secara ilmiah dan mampu mengatasi permasalahan yang berhubungan dengan lingkungan siswa. Sesuai dengan tuntutan kurikulum 2013 bahwa pembelajran di Sekolah Dassar lebih ditekankan pada aspek sikap, pengetahuan, dan keterampilan. Siswa juga difokuskan agar lebih aktiif dalam menemukan, mengolah, mengkontruksi pengetahuannya, serta dapat berpikir ilmiah dalam upaya menyelasaikan permasalahan yang berkaitan dengan kehidupan siswa. Oleh karena itu, pembelajaran di Sekolah Dasar harus mengacu pada standar isi kurikulum 2013. Standar isi memuat materi-materi pembelajaran yang telah tertuang dalam sumber belajar kurikulum 2013.

Sumber belajar merupakan bagian yang sangat penting dalam pelaksanaan pembelajaran terutama pada jenjang Sekolah Dasar yang menuntun siswa aktif dalam mencari, menemukan, dan menggali. Menurut (Juwita, 2017) "sumber belajar merupakan salah satu komponen penting dalam proses pembelajaran yang disusun secara sistematis serta menampilkan sosok utuh kompetensi yang akan dikuasai oleh siswa dalam proses pembelajaran". Sumber belajar yang utama dalam kurikulum 2013 adalah buku teks pelajaran. Berdasarkan Permendikbud No 8 Tahun 2016 Pasal 1 ayat (1) menyatakan bahwa buku teks pmebelajaran meruapakan sumber belajar yang utama dalam pencapaian Kompetensi Inti dan Dasar serta sudah disahkan dan dinyatakan layak digunakan oleh Kementerian Pendidikan dan Kebudayaan untuk digunakan di Satuan Pendidikan.

Meski buku yang diterbitkan oleh pemerintah telah disusun dengan sebaik-baiknya namun sesuai perubahan zaman, maka buku akan terus diperbaiki dan dirubah untuk memenuhi perkembangan zaman itu sendiri. Oleh sebab itu, diperlukan masukan-masukan demi meningkatkan kualitas buku. Dengan adanya perubahan atau revisi dari buku teks, sehingga memunculkan pertanyaan terkait kesesuaian materi pembelajaran dengan standar isi. Selain itu, mengingat buku yang diterbitkan oleh pemerintah adalah untuk skala nasional, maka sebelum menggunakannya perlu dilakukan analisis terlebih dahulu untuk menyesuaikan dengan kebutuhan siswa dalam mencapai kompetensi yang telah ditetapkan. Jika ditemukan ketidaksesuaian pada buku maka dapat ditindaklanjuti dan diperbaiki lebih awal.

$\begin{array}{lrr}\text { Pemerintah } & \text { juga } & \text { telah } \\ \text { mengeluarkan } & \text { peraturan } & \text { yang }\end{array}$
tercantum dalam Permendikbud Nomor 8 Tahun 2016 Pasal 9 ayat (2) yang menyebutkan bahwa Satuan Pendidikan wajib melaksanakan penilaian kepada semua buku yang dipakai di Satuan Pendidikan untuk memenuhi kriteria tertentu. Oleh karena itu, diperlukan adanya penelitian yang mengkaji mengenai 
kesesuaian materi yang ada pada buku siswa terhadap standar isi kurikulum 2013 untuk meningkatkan kualitas dari isi buku tersebut.

Berdasarkan hasil observasi yang dilakukan di beberapa Sekolah Dasar ditemukan permasalahan yaitu sekolah belum melakukan evaluasi mengenai kesesuaian buku dengan kebutuhan siswa dan kesesuaian buku dengan kompetensi dalam kurikulum 2013. Oleh karena itu, penulis melakukan analasis awal terhadap buku yang digunakan di Sekolah Dasar yaitu buku terbitan Kemendikbud.

Berdasarkan hasil penelitian yang dilakukan oleh (Mawardi, 2018) menyebutkan bahwa hasil analisis yang dilakukan peneliti terhadap buku siswa menemukan adanya kelemahan pada deskripsi tema dan sub tema, jika dilihat dari kacamata hakikat pembelajaran tematik terpadu. Pada buku siswaa kelas IV, tema 4 Brbagai Pekerjan, subtema 1 Jeniis-jenis Pekerjaan, materi Pembelajaran 1 sampai 6 seharusnya membahas materi dengan mengacu pada subtema Jenis-jenis pekerjaan secara konkret. Kenyataannya subtema jenis-jenis pekerjaan masih sangat umum dan belum konkret, sehingga pembelajaran menjadi kurang bermakna. Oleh karena itu, perlu dilakukannya analisis terhadap buku siswa hal ini dilakukan untuk melihat permasalahan dalam buku tersebut.

$$
\text { Adapun tujuan dalam }
$$

peneliitian ini yaitu untuk mengetahuii kesesuaian materi IPA buku siswa kelas IV terhadap standar isi kurikulum 2013.

\section{METODE PENELITIAN}

Penelitian ini menggunakan jenis penelitian studi kepustakaan (Library Research) dengan pendekatan penelitian kualitatif. Studi kepustakaan merupakan suatu studi yang digunakan untuk mengumpulkan informasi atau pengumpulan data pustaka dengan membaca dan mencatat serta mengolah bahan penelitian. Ciri-ciri dari studi kepustakaan adalah peneliti berhadapan langsung dengan teks atau naskah, data kepustakaan bersifat tetap dan siap pakai, data pustaka umumnya adalah data sekunder dalam arti peneliti mendapatan data dari tangan kedua dan bukan data orisinil dari tangan pertama di padangan, dan kondisi data pustaka tidak dibatasi oleh ruang dan waktu (Zed, 2014).

Teknik pengumpulan data yang digunakan yaitu studi dokumentasi yaitu teknik pengumpulan data yang dilakukan dengan menganalisis isi dokumen yang berhubungan dengan masalah yang diteliti. Menurut Gunawan, analisis dilakukan dengan cara membandingkan dan memadukan dokumen-dokumen untuk membentuk suatu hasil kajian yang sistematis (Gunawan, 2013). Sumber data yang digunakan yaitu berupa buku siswa kelas IV kurikulum 2013.

Adapun analisis data yang digunakan merupakan analisis konten (content analysis). 
Weber menyatakan "analisis konten merupakan penelitian yang

HASIL PENELITIAN PEMBAHASAN

memanfaatkan seperangkat prosedur untuk menarik kesimpulan yang sahih dari sebuah buku atau dokumen".

\begin{tabular}{|c|c|c|c|c|c|c|c|c|c|c|c|}
\hline \multirow[t]{2}{*}{ 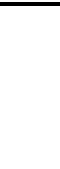 } & \multirow[t]{2}{*}{ Kompetensi } & \multirow[t]{2}{*}{$\begin{array}{c}\text { Ruang Lingkup } \\
\text { Materi }\end{array}$} & \multicolumn{9}{|c|}{$\begin{array}{l}\text { Kesesuaian materi dengan ruang } \\
\text { lingkup materi IPA pada Tema 1-9 }\end{array}$} \\
\hline & & & 1 & 2 & 3 & 4 & 5 & 6 & 7 & 8 & $\overline{9}$ \\
\hline- & $\begin{array}{l}\text { Menunjukkan } \\
\text { sikap dalam } \\
\text { kegiatan ilmiah: }\end{array}$ & $\begin{array}{l}\text { Bentuk dari luar } \\
\text { tubuh hewan dan } \\
\text { tumbuhan }\end{array}$ & & & $\mathrm{V}$ & & & & & & \\
\hline & $\begin{array}{l}\text { jujur, logis, dan } \\
\text { disiplin melalui } \\
\text { IPA }\end{array}$ & $\begin{array}{l}\text { Daur hidup } \\
\text { makhlukk hidup }\end{array}$ & & & & & & V & & & \\
\hline- & Dapat & $\begin{array}{l}\text { Perkembangbiakan } \\
\text { tanaman }\end{array}$ & & & & & & & & & \\
\hline & $\begin{array}{lr}\text { pertanyaan } & \text { aapa, } \\
\text { mengapa, } & \text { dan }\end{array}$ & Wujud dari benda & & & & & & & & & \\
\hline _- & alam sekitar. & Gaya dan gerak & & & & & & & $\mathrm{v}$ & $\mathrm{V}$ & \\
\hline & $\begin{array}{l}\text { pengamatana objek } \\
\text { IPA dengan } \\
\text { menggunakan }\end{array}$ & $\begin{array}{l}\text { Bentuk dan } \\
\text { sumber energi dan } \\
\text { energi alternatif }\end{array}$ & & V & & & & & & & V \\
\hline- & $\begin{array}{l}\text { panca indra dan } \\
\text { alat sederhana } \\
\text { Mencatat serta }\end{array}$ & $\begin{array}{l}\text { Rupa bumi dan } \\
\text { perubahannya }\end{array}$ & & & & & & & & & \\
\hline & $\begin{array}{l}\text { menyajikan data } \\
\text { hasil pengamatan } \\
\text { alam }\end{array}$ & $\begin{array}{l}\text { Ligkungan, alam } \\
\text { semesta, dan SDA }\end{array}$ & & & V & $v$ & & & & & \\
\hline- & $\begin{array}{l}\text { secara sederhana } \\
\text { Melaporkan hasiil } \\
\text { pengamatan alam } \\
\text { sekitar secaraa } \\
\text { lisan dan tulisan } \\
\text { secara sederhanaa } \\
\text { Mendeskripsikan } \\
\text { konsep SAINS } \\
\text { berdasarkan hasil } \\
\text { pengamatan }\end{array}$ & Iklim dan cuaca & & & & & & & & & \\
\hline
\end{tabular}

\section{Pembahasan}

Kesesuaian materi IPA dengan ruang lingkup materi yang ada pada standar isi kurikulum 2013 yaitu untuk materi mengenai "bentuk luar tubuh hewan dan tumbuhan, daur hidup makhluk hidup, gaya dan gerak, bentuk dan sumbere enegi dan energi alternativ, lingkungan, alam semesta, dan sumber daya alam sudah sesuai dengan materi yang disajikan pada buku siswa kelas IV SD. Namun, ternyata terdapat ketidaksesuaian 
yaitu pada tema 1 mengenai siifatsifat bunyi dan kaitanya dengan indra pendengaran dan tema 5 mengenai sifat-sifat cahaya dan kaitanya dengan indera penglihatan. Materi IPA yang terdapat pada buku siswa ternyata tidak ditemukan pada ruang lingkup materi IPA pada standar isi. Pada ruang lingkup materi juga ditemukan beberapa materi yang tidak terdapat pada buku siswa yaitu materi tentang wujud benda, perkembangbiakan tanaman, serta materi tentang iklim dan cuaca.

\section{SIMPULAN}

Dari hasil analisis kesesuaian dapat disimpulkan bahwa materi IPA buku siswa kelas IV SD sesuai dengan standar isi kurikulum 2013. Namun, dari penelusuran terdapat sembilan runag lingkup materi IPA dalam standar isi kurikulum 2013 ada tiga materi IPA yang tidak disajikan dalam buku siswa yaitu wujud benda, perkembangbiakan tanaman, serta materi tentang iklim dan cuaca. Selain itu, terdapat dua materi tambahan dalam buku siswa yaitu mengenai sifat-sifat bunyi dan sifat-sifat cahaya yang tidak terdapat dalam standar isi kurikulum 2013

\section{DAFTAR RUJUKAN}

Amelia, J. D, Saputra, Y, S. 2017. Kelayakan Buku Siswa Kelas IV Tema Makhluk Hidup Kurikulum 2013. Jurnal Pendidikan: 6(1), 2548-2254.

Gunawan, I. 2013. Metode Penelitian Kualitatif (Teori dan Praktik). Jakarta: Bumi Aksara.
Juwita, T., Ilmiyati, N, \& Maladona, A. 2017. Kelayakan Buku Pembelajaran IPA Kurikulum 2013 pada Materi Sistem Pencernaan Kelas VIII yang Digunakan dalam Proses Pembelajaran Ditinjau dari Relevansi Isii, Ketepatan dan Kompleksitas. Jurnal Bio Education: 2(1), 2541-2280.

Kemendikbud. 2016. Permendkbud

Nomor 21 Tahun 2016 tentang Standar Isi Pendas dan Menengah. Jakarta:

Kemendikbud.

Kemendikbud. 2016. Permendikbud

No 8 Thn 2016 tentang Buku yang Dipakai oleh Satuan Pendidikan. Jakarta:

Kemendikbud.

Mawardi, Wardani, Hardini, Kristin.

2019. Model Disain

Pembelajaran Tematik

Kontekstual dalam Peningkatan Kebermaknaan Belajar Siswa SD. Jurnal Pendidikan dan Kebudayaan: 9(1).

Zed, M. 2014. Metodde Peneltian Kepustkaan. Jakarta: Yayasan Pustaka Indonesia 